\title{
POLITICAL PARTIES IN PAPUA NEW GUINEA
}

R. J. May

AT THE TIME of PNG's independence in 1975, there was a small number of recently established political parties. The Australian Colonial Administration had had some doubts about encouraging the growth of parties in the emerging state, but, in the late 1960s, as parties spontaneously emerged, it extended its political education program to cover them. There was a widespread expectation, at independence, that a two- or threedominant-party system would develop, in the context of a first-past-the-post electoral system, though there were some who feared that PNG, like much of post-colonial Africa, would succumb to military rule or a dominant one-party regime. In fact, as in a number of post-colonial states, a coherent political party system has not taken root in PNG. This is so despite the fact that elections have been held regularly and have produced orderly changes of government, and that, despite some pre-independence predictions, the country has maintained a democratic parliamentary system.

In a paper written in 1984 , I questioned the apparently widespread assumption that the 'party system' in PNG was in a state of transition from an 'undeveloped' to a 'developed' system (that is, essentially one like Australia, the UK, the US and some European countries), and specifically challenged the view that the party system would solidify along emergent social class lines. ${ }^{1}$ Some 20 years later, political party development in PNG - or the lack of it - has tended to strengthen those convictions. This chapter, therefore, attempts, after presenting a brief history of political parties, to examine the main features of political parties in PNG, to look at attempts to strengthen the political party system through legislation, to explain why parties have not developed as many predicted in the 1970 s and 1980s, and, finally, to speculate on the future for political parties in the country.

\section{A brief history of political parties ${ }^{2}$}

In the lead-up to PNG's independence, the Australian Administration progressively, if perhaps somewhat belatedly, established the institutions of an essentially Westminster 
parliamentary democracy. A part-elected, part-appointed House of Assembly was created in 1964, replacing an appointed Legislative Council, and further elections were held in 1968 and 1972, the latter producing the country's first wholly elected Parliament.

Initially, there was little enthusiasm for political parties. As late as 1967, Australia's External Affairs Minister, Charles Barnes, suggested that 'the Territory would be better off without [political] parties', ${ }^{3}$ and this view was shared by many field officers of the Australian Administration, who tended to be wary of any indigenous political organisation and disparaging of attempts to establish political parties. ${ }^{4}$ Recalling his unsuccessful electoral campaign in 1967, Albert Maori Kiki said:

Many people had told me that it was unwise to campaign on the Pangu platform, that the administration had tried to discredit us and that it could be used against me. In fact most of the Pangu candidates, even the ones from the inner circle, campaigned as individuals in order not to expose themselves to this kind of attack. ${ }^{5}$

Even as the 1972 elections approached, some officials of the Australian Administration 'foster[ed] the attitude that parties were detrimental to the country'. 6

Despite this, political education material prepared by the Administration before the elections of 1968 and 1972 commended political parties, specifically supporting the idea of two or three parties over one or many, ${ }^{7}$ and, after a visiting UN mission in 1971 had recommended that parties be promoted on a nationwide basis, ${ }^{8}$ the Administration distributed a booklet on parties that contained the platforms of the three major parties at that time. Indeed, by the early 1970s, it might be said that the Administration was propagandising for the institution of political parties as some well-informed Papua New Guineans were arguing against parties as being potentially disruptive.

Inhibiting factors aside, mass-based political movements did emerge in the preindependence period. Among the various political organisations to appear on the scene vefore the elections for the second House of Assembly in 1968, two - the United Christian Democratic Party (later United Democratic Party - UDP) and the Papua New Guinea National Union (Pangu Pati) — might be described as the first indigenous, mass-based parties. The UDP, an ideologically conservative party identified with the Catholic mission, was established in the East Sepik Province in 1966, but proved to be short-lived, fading away after a disappointing showing in the 1968 election. Pangu was more successful: when the second House of Assembly sat in 1968, 10 of the 84 members were Pangu members, and the party declared itself to be the 'loyal opposition' to the Administration-dominated 'government'. Nevertheless, a study of the 1968 election, echoing Kiki's comments, minimised the influence of parties in the election:

Outside a handful of towns, there was little sign of the 'political parties' so hastily inaugurated during 1967 ... At worst ... it was an electoral liability for a candidate to be publicly associated with them, and candidates ... avoided or even denied such association. ${ }^{9}$

And Ted Wolfers observed: 
Parties probably had a real impact at the popular level only in the East Sepik, Bougainville and Morobe districts. ${ }^{10}$

Between 1968 and 1972, two other mass-based movements emerged, which were described at the time as political parties. ${ }^{11}$ These were the Mataungan Association of East New Britain and Napidakoe Navitu of the North Solomons. But though both movements fielded candidates in the election of 1972 (and the Mataungans again in 1977), they were not formed as political parties to contest elections. ${ }^{12}$ Before the end of the 1968-72 House of Assembly, three more political parties had emerged. The first of these, the United Party, had its origins in an Independent Members' Group (IMG) established in the House in 1968 among a group of members brought together essentially by their opposition to Pangu's demand for early independence. The group consisted largely of Highlands members together with some of the more conservative expatriate members. In 1968-69, attempts were made by members of the IMG to create local groups to support a political party centred on the IMG and, in early 1970, the formation of a coordinating body, Combined Political Associations (Compass), was announced. Its chairman and secretary were both Highlanders. The next year, Compass changed its name to United Party (UP). By mid 1971, UP claimed the backing of 45 parliamentary members. A second party also emerged from within the IMG in 1970: the Business Services Group, under the leadership of Julius Chan, comprised 10 members, mostly from the New Guinea Islands, who, it was suggested 'seemed to represent a regional distrust of the highlands leadership implicit in Compass'. ${ }^{13}$ The Business Services Group subsequently founded the People's Progress Party (PPP). The association of Highlanders with a 'go-slow' attitude to independence, which Compass represented, also prompted the formation among a group of generally younger and more progressive Highlanders of the New Guinea National Party (NP), which was generally regarded as 'the highlands equivalent of Pangu. '14

The 1972 election was thus, for the first time, contested by parties. About 150 of the 611 candidates who nominated were endorsed or selected and helped by parties, ${ }^{15}$ and in his overview of the election David Stone concluded that 'Undoubtedly ... what marked the 1972 general election from its predecessors was the prominent and active participation by political parties and associations. ${ }^{16}$ Nevertheless, some candidates were still hesitant about publicly admitting party membership, and party organisation was still weak: as in 1968, a number of electorates fielded more than one candidate from the same party, and no party had a nationwide organisation. In the event, no party emerged from the 1972 elections with a clear majority and, notwithstanding the expectations of the UP (which had anticipated up to 60 seats and in fact won about 37), after some intense lobbying of members elected without formal party commitment, Pangu leader Michael Somare was able to cobble together a National Coalition Government, which embraced Pangu (with 18 endorsed candidates winning, and additional pro-Pangu members bringing its numbers to 26), PPP (11), NP (eight), the Mataungan Association (three) and eight independents. This post-election lobbying of apparently unattached members set a precedent for all subsequent elections. The UP accepted the role of Opposition, and this party alignment was broadly maintained during the life of the 1972-77 Parliament (though in 1975 some UP members supported the Government on critical divisions). 
In 1972, a Constitutional Planning Committee was appointed to begin the process of preparing a constitution for the independent state. Its Final Report (1974) contained only a brief comment on political parties, proposing that parties be registered and supporting the idea of public funding for parties. The Constitution subsequently provided that organic laws would make provision to ensure the integrity of political parties and candidates, ${ }^{17}$ but 25 years later this had not been done.

Between 1972 and the first post-independence election in 1977, there were several significant developments in the incipient party system. One was the emergence of the Nationalist Pressure Group (NPG) in 1974. The NPG represented a coalescence of members who supported the proposals of the Constitutional Planning Committee against modifications put forward by the Government. ${ }^{18}$ Although it voted as a cohesive group on 'national' issues in 1974-75, the NPG specifically avoided the label 'party' and its 18 core members - drawn from the four major parties plus the Mataungan Association and a newly formed Country Party (whose members were recruited mostly from the UP) - retained their party affiliations. Another development was the election, in a by-election in 1976, of a second member representing the separatist Papua Besena movement, whose leader, Josephine Abaijah, had been elected in 1972, and the subsequent announcement of a Papua Party. ${ }^{19} \mathrm{~A}$ third was the split and virtual collapse of the NP in 1976, after Somare had dismissed from Cabinet its leader and deputy leader, and a move by them to withdraw all NP members from the coalition failed. The NP split provides an early example of the way in which parties have fractured when some party members have jockeyed for a place in a new coalition while others have wanted to hold on to ministerial portfolios. By the end of the 1972-77 Parliament, party allegiances, as well as coalition ties, were looking fragile and there were calls for variously an all-party system and a no-party system.

In 1977 , the party mass organisations, which had generally atrophied since 1972, were revived for the country's fourth and inaugural post-independence election. This time, of the 879 candidates who contested the 109 seats, 295 (30 per cent) were endorsed by one, or more, of the three major parties. ${ }^{20}$ In addition, a number of Papuan candidates stood for Papua Besena, which in 1977 appeared to have evolved from an illdefined separatist movement to a fully fledged political party. Observers of the 1977 poll seem to have been generally agreed that political parties had a substantial impact on the election, ${ }^{21}$ though in an interim report on the election Bill Standish concluded that while in the towns, competition 'was more in terms of modern associations', in rural areas 'clan voting prevailed'. 22 In 1977, as in 1972, uncertainties about the political allegiances of some candidates resulted in intense post-election lobbying among those who hoped to be able to put together a government. One proposal was for a 'National Alliance' including UP, Papua Besena, the Country Party and NP. Another was for an Islands-based Alliance for Progress and Regional Development, led by the two former NPG spokesmen, John Momis and John Kaputin. In the event, the successful combination was a coalition of the enlarged Pangu and PPP membership (38 and 20 respectively) with most of the Mataungan and North Solomons members and two UP defectors, led by Somare. After several months of infighting within the Opposition, former NP 
minister Iambakey Okuk emerged as Opposition Leader. Having attempted unsuccessfully to bring together his Highlands supporters, Papua Besena members and some others in a People's United Front, Okuk revived the NP and, as its leader, waged an aggressive campaign against the Coalition.

In November 1978, after a growing unease in the relationship between PPP and Pangu (which had probably more to do with personalities and leadership styles than with policies), PPP withdrew from the Coalition. Pangu was maintained in office by a split within the UP, which brought about half of that party's members across the floor to the Government. In 1978-79, the Somare Government survived three no-confidence motions initiated by Okuk, but in January 1980, after a Cabinet reshuffle, Momis and Kaputin withdrew from the Coalition, forming a new party, the Melanesian Alliance (MA), and, two months later, with their support, a no-confidence vote against the Somare Government succeeded. Chan became Prime Minister as the head of a National Alliance Government comprising PPP, NP, MA, Papua Besena and part of UP.

The Alliance was able to hold on to office until the scheduled elections of 1982, but it was, to say the least, an improbable coalition. PPP and NP, broadly aligned in support of capitalist development and foreign investment (though with little personal empathy between Chan and $\mathrm{Okuk}^{23}$ ), were at one end of a political spectrum from the MA, which regarded itself as being to the left of Pangu and whose leaders were strongly identified with economic nationalism and the aim of self-sufficiency; and Papua Besena, which owed its origins in large part to fear and distrust of Highlanders, ${ }^{24}$ was a strange bedfellow for a coalition in which Highlands members were a large component and whose deputy leader (Okuk) was a staunch Highlands nationalist.

Between 1977 and 1981, extra-parliamentary party organisation, such as it was, had again atrophied, but party organisations were resuscitated in the lead-up to the 1982 elections and several new groupings appeared. Indeed, in the 1982 elections, parties seemed to be more salient than ever. Pangu, PPP, UP, NP, MA and Papua Besena/Papua Party all fielded candidates, while two new groups - a Papua Action Party (which had links with the NP) and a predominantly Papuan 'Independent Group' headed by former Defence Force Commander Ted Diro - emerged as significant contenders. Some 59 per cent of the 1,125 candidates who stood in 1982 were endorsed by one or more of these eight parties. ${ }^{25}$ My own observation of the 1982 campaign in the East Sepik suggested not only that nearly all candidates sought a party label (some, indeed, more than one) but that a high proportion of voters could accurately attach party labels to most candidates; nevertheless, 'party organization was still fairly rudimentary and ... local and kin ties and exposure to the electorate were still critically important' ${ }^{26}$

Notwithstanding this, party attachment for most candidates seemed still to be loose and it was not rare for a candidate who failed to get endorsement or assistance from one party to turn to another; for some parties and in some electorates, party attachment meant little more than the use of a label. Further, in a number of instances, party members stood against endorsed candidates of their own party against their party's interests (though in some cases, parties — especially Pangu — supported more than one candidate in order to split the local vote of opponents of their endorsed candidate). 
Overall, it seemed that although there was in 1982 some increase in party voting, personal and local loyalties were still considerably more important for the majority of voters. $^{27}$

The outcome of the 1982 election was a victory for Pangu, which — apart from the recently established MA - was the only party to increase its representation in the Parliament. Somare was duly re-elected to the Prime Ministership, heading a government comprising Pangu (with 50 members), UP (six) and a number of members who were either elected as independents or switched from other parties after the election. Diro emerged as Opposition Leader, and, surprisingly, Parliamentary Leader of the NP, after Okuk had lost his seat in Simbu; but when, in 1983, Okuk was returned in a by-election, Diro stepped down from both posts in Okuk's favour. The MA aligned itself with the NP/Independent Group and Papua Party in opposition, but the PPP for a while occupied the middle benches.

In 1985-86, Pangu Pati suffered two splits. The first occurred when a group of 15 members led by Deputy Prime Minister Paias Wingti (a Highlander, who had been elected as a UP candidate but switched to Pangu in 1977) left to form a new party, the People's Democratic Movement (PDM). The second came in early 1986 when a small group of senior Pangu members, led by Somare's Sepik colleague Anthony Siaguru, formed a Pangu Independent Group (PIG). The PIG sought acceptance as an 'affiliate' of Pangu, but when this was refused they broke away to form the League for National Advancement. The Somare Government survived a vote of no confidence early in 1985 with support from the NP and MA, but in November a vote of no confidence went against Somare, and Wingti became Prime Minister, leading a coalition consisting of PDM, PPP, NP and some Pangu, UP and MA defectors. During 1986, there was tension within the Coalition, particularly between Wingti, Okuk (until his death in late 1986) and Chan, but the Coalition was still intact when Parliament rose for the 1987 election.

As the 1987 election approached, five new parties emerged, including the People's Action Party (PAP), a Papuan-based party led by Diro, which drew on the support for the earlier Papuan Action Party and Diro's Independent Group, and the Morobe Independent Group (MIG) headed by former student leader and Morobe Premier, Utula Samana. This gave a total of 15 parties. Despite the increased number of parties, the percentage of partyendorsed candidates among the 1,513 candidates nominating dropped to 37 , and independents won 22 of the 109 seats. In a pre-election survey of voters conducted by Yaw Saffu, to the question 'What is it that you would look for in the candidate you will be voting for?', only 3.4 per cent of respondents answered 'Party'. ${ }^{28}$ When votes were counted, Pangu had 26 seats, PDM 17, NP 12, MA seven, PAP six, PPP five, MIG four, LNA three, Papua Party three and UP one. Elections for the three remaining seats were postponed. It was widely expected that Somare would be able to put together a winning coalition, but in the event it was Wingti who was successful, emerging as the leader of what Somare described as 'a ramshackle gaggle of unruly independents' ${ }^{29}$ which included the PPP and a newly formed Papuan Bloc led by Diro, which included PP, PAP and some independents.

In the next months, the governing coalition came under severe strain. Diro, who had served as Minister for Forests in the previous Wingti Government, had been named 
in an investigation into the forestry industry and faced a leadership tribunal as well as perjury charges; it was also disclosed that he had received 'campaign contributions' of almost \$A180,000 from Indonesian Armed Forces Commander, Benny Murdani, contrary to the provisions of PNG's Constitution. Notwithstanding this, Diro continued to press for appointment as Deputy Prime Minister and for more Cabinet posts for the Papuan-dominated PAP, and failed to dissociate himself from rumours of an impending coup, after Wingti had removed the commander of the PNG Defence Force (PNGDF) and three colonels, all of whom were Papuans. Kaputin, who had been expelled from the MA for joining the Wingti Coalition in 1985, initiated a meeting of New Guinea Islands' members (attended by 10 of the 17 Islands members), which called for 'political stability, social justice and a return to the principles of democracy'. And there were defections from the governing coalition, one member referring to the Government as 'morally corrupt'. Facing a vote of no confidence, the Government adjourned Parliament. During the adjournment there were, first, moves for a 'grand coalition' including PDM, PPP and Pangu, over which talks collapsed, and then the signing of an 'irrevocable memorandum of understanding' for the formation of a Government of National Reconciliation, embracing PDM, PPP, Pangu, PAP and Samana's renamed Melanesian United Front (MUF). But while Wingti was signing an agreement with Pangu, he was secretly negotiating with the NP (then led by Wingti's fellow Highlander Michael Mel), and, in a Cabinet reshuffle in June 1988, NP was dealt in and Pangu excluded.

A motion of no confidence was foreshadowed as soon as Parliament met later that month, and there was a spate of defections from PDM. The NP also split, again. In the subsequent vote, a combination of Pangu (including a few members who defected back to Pangu), most of the Papuan Bloc, the MA, LNA, a faction of NP and a few others prevailed over Wingti's leadership, and Rabbie Namaliu, who had replaced Somare as Parliamentary Leader of Pangu in July 1988, became PNG's fourth Prime Minister.

Despite the enlightened leadership of Namaliu, and the passage of a budget of 'unity, reconciliation and reconstruction', the period from mid-1988 to 1992, when the next election took place, was turbulent. It saw the start of the Bougainville rebellion, unrest within the PNGDF, economic downturn and escalating problems of law and order. Several votes of no confidence were initiated, and Parliament was adjourned for further long periods in 1989 and 1990. In 1991, the Constitution was amended to extend the initial grace period for votes of no confidence from six months to 18. There were several Cabinet reshuffles, which, among others, saw Diro eventually achieve the position of Deputy Prime Minister, a position he held until April 1991, when he was found guilty of 81 counts of misconduct under the Leadership Code. The decision of the Leadership Tribunal in the Diro case precipitated a brief constitutional crisis when the Governor-General, a Papuan and former president of the PAP, refused to sack Diro. The tensions brought about by all this political activity saw a split in the PAP, defections from PDM and PPP, and from Pangu, and several parties expelled rebellious MPs.

Commenting on Wingti's political machinations in mid-1988, Saffu suggested that 'Wingti's modus operandi had helped to raise the levels of cynicism and deception in PNG politics. ${ }^{30}$ Indeed, the well-publicised comings and goings in the Parliament of 
1987-92 left many people cynical about political parties, and, although there was, once more, something of a revival of extra-parliamentary party activity in the lead-up to the 1992 election, parties seem to have been less salient in 1992 than in the previous two or three elections. ${ }^{31}$ Six of the parties that had contested in 1987 had disappeared (including Samana's MIG/MUF, Papua Besena and the Papua Party), and several new parties emerged, including the People's Solidarity Party (PSP), a breakaway from the PAP. The PSP polled well (probably in part at the expense of the PAP), but failed to win a seat and subsequently faded away.

In 1992, the fee for candidature was raised from K100 to K1,000 in an attempt to counteract the growth in the number of candidates standing, but the number continued to rise, to 1,655. Of these, 75 per cent chose to stand as independents. In 1987, the seven major parties (Pangu, PPP, PDM, MA, PAP, LNA and NP) won 51 per cent of votes and 76 seats; in 1992, their share of the vote fell to 32 per cent and they won 68 seats. ${ }^{32}$ Pangu was the most successful party, but its percentage of the total vote fell from 34 to 9 per cent and seats won from 50 to 20. In the vote for Prime Minister, Wingti, in coalition with the PPP, LNA and a group of independents, defeated Namaliu by a single vote. As in every Parliament to date, there was a mid-term change of government in 1994 when, having resigned and been re-elected as Prime Minister in a move to avoid a vote of no confidence, Wingti was removed after a Supreme Court ruling against his action. In the reshuffling that followed, PPP leader Chan became Prime Minister, outvoting prominent Port Moresby politician Bill Skate of the Papua New Guinea First Party (PNGFP); Chan headed yet another coalition government, in partnership with Pangu. Chris Haiveta, who had succeeded Namaliu as Pangu leader, became Deputy Prime Minister.

In 1997, there was a major political upheaval when the Chan Government, having secretly negotiated a contract with 'military consultants' Sandline International to bring an end to the Bougainville rebellion, was challenged by the Commander of the PNGDF, Brigadier General Singirok. Singirok denounced the contract, detained the Sandline mercenaries and called on Chan, Haiveta and the Defence Minister to stand down. An inquiry was set up and a major crisis averted, but in the ensuing election Chan lost his seat.

Once again, there was a proliferation of parties on the eve of the 1997 election. New parties included the People's National Congress (PNC), which replaced the PNGFP as Skate's Papuan-based party; the Movement for Greater Autonomy (MGA), a New Guinea Islands-based party headed by former Manus Premier, Stephen Pokawin; and the National Alliance (NAL). In 1995, Somare, then a member of the Chan Government, had opposed legislation that fundamentally changed the country's provincial government system. As a result, he was dropped from Cabinet and became alienated from some of his Pangu colleagues. He subsequently founded the NA as a new political grouping, comprising the MA, the MGA (which also had its origins in the provincial government debate), some Pangu supporters and progressive independents. Somare used the NA as his electoral vehicle in 1997. Of the 2,372 candidates contesting, 712 were listed as having party attachment, though parties in 1997 seemed to have fewer resources to offer and party leaders seemed to be less active outside their own electorates. On these figures, 
the proportion of independents fell slightly, to 70 per cent, though the actual number rose. PAP fielded the largest number of candidates; surprisingly, given its Papuan origins, more than half of these were in Highlands electorates, where there were multiple PAP candidates in a number of electorates.

When votes were counted, PPP (which had won eight seats in 1992 but had seen its support grow to 32 before the parliamentary recession of 1997) had 16 seats; Pangu had also lost ground, gaining 13 seats; the NA had 11 (including four MA seats); PDM nine; NP seven; PNC six (all in Papuan electorates); PAP six, and there were 38 independents. In the scramble for numbers prior to Parliament sitting, it looked as though Somare would emerge on top. The NA-led coalition failed to get the numbers in Parliament when Skate, who had promised support for Somare, took his PNC into a rival grouping and was rewarded with the Prime Ministership.

The Skate Government faced several minor crises between 1997 and 1999 mostly self-made. In December 1998, there was another long adjournment of Parliament designed to avoid a vote of no confidence (between July 1998 and June 1999, Parliament met for only 17 days). Tensions had emerged between Skate and Haiveta, and when, in 1999, Skate dropped Haiveta from Cabinet, Pangu withdrew from the Coalition and backed the PDM in a successful move to oust Skate. Wingti having lost his seat in 1997, the leadership of PDM was assumed in 1998 by former Treasury Secretary and Central Bank Governor, Sir Mekere Morauta, who had stood as an independent in 1997 and had been a minister in the Skate Government before becoming one of 12 ministers sacked by Skate. In the vote for Prime Minister, Morauta won by 99 votes to five — with Skate voting for him! Morauta thus became PNG's sixth Prime Minister. In 2001, a number of members switched allegiance to the PDM, giving it for a while an absolute majority in Parliament, but the 2002 elections saw a shift away from the party (see below).

\section{Characteristics of political parties in PNG}

It is impossible, within a short space, to detail the constant comings and goings of members, defecting from one party and joining another, sometimes only temporarily, and the constant wheeling and dealing among party leaders seeking to advance their party's interests or their own ministerial aspirations through the formation of new coalitions or the preservation of existing ones. The brief history above conveys something of the flavour of party politics in PNG and provides a broad context within which some of the particular characteristics of political parties and the 'party system' in PNG can be highlighted.

\section{Party organisation}

Typically, political party organisation in PNG has been weak. Although, on paper, some of the larger parties have had organisational structures based on party branches, most parties have been essentially parliamentary alliances and have been dominated by prominent parliamentary members (or, in a few cases - the PPP with Julius Chan and the PDM with Paias Wingti - by former MPs who hoped to be re-elected). In between elections, party organisations in the electorate, such as they exist, have tended to lie dormant. Even 
Pangu, which in the 1970 s and 1980s probably came closest to maintaining an effective organisation - at least in its strongholds of East Sepik and Morobe Provinces — found it difficult to sustain popular support.

As a result, the textbook functions of a political party in formulating policy options, recruiting supporters and selecting candidates have seldom been fulfilled in PNG. Indeed, rather than having party branches that select candidates from among their numbers for the open and provincial electorates, in most parties it is the party leader who seeks out and recruits likely candidates for party endorsement, frequently from outside the party.

Lack of mass membership has also affected party finances. In the elections of 1968 to 1987, the larger parties were generally able to offer financial and logistical support during election campaigns - financing candidate deposits and the printing of posters, providing vehicles, boats or outboard motors for campaigning and sometimes providing T-shirts or cash. Indeed, in the 1970s, several major parties had established 'business arms' to generate campaign funds. In the 1990s, most business arms seem to have been depleted and party funding for endorsed candidates seems to have substantially dried up. When funds were forthcoming to support party candidates, party leaders seem to have been the predominant source, strengthening the personalistic tendency in party identity.

In Parliament, party discipline has generally been weak, the institution of party whips not having become well entrenched, and, from an early stage, 'party-hopping' or 'yoyo politics' has been fairly commonplace.

Associated with the fluidity of party attachment has been a rise in the number of candidates standing as independents. Often such 'independents' have known party leanings and might have accepted campaign support from parties that might have endorsed another candidate, but have left themselves relatively free so that, if elected, they can 'sell' their parliamentary support to the party that makes the best offer. This has given rise to a particularly Papua New Guinean practice: after the declaration of candidates after elections, two or three camps are set up, generally well away from Port Moresby (even as far as Australia), by powerbrokers for the major parties, and attempts are made to physically assemble winning coalitions of elected members. Substantial inducements might be offered to attract members to a coalition, and, on occasion, there have been complaints that members have been held at such camps against their will (hence the term sometimes used for such occasions - 'lock-ups').

\section{Bases of party differentiation}

The ease with which some MPs have changed party allegiance reflects partly a lack of clear ideological (or other) differences between parties. In the period before independence, Pangu, together perhaps with the NP, was differentiated from the other parties primarily by its critical attitude towards the Australian Administration and its demand for early independence. The UP preferred a longer transition to independence, reflecting the view of its predominantly Highlander membership that they needed more time to 'catch up' with the coastal people, who had had a longer period of contact with the Colonial Administration and enjoyed higher levels of education and public sector employment. With the achievement of independence in 1975, this ceased to be a point 
of differentiation. Otherwise, the UP and PPP were generally regarded as more 'business' oriented and more favourably disposed towards foreign participation in the economy than Pangu, whose associations included trade unionists. But in practice the differences were not substantial, as the record of the first coalition government (1972-77) demonstrated. Indeed, on the one occasion that substantial differences on important policy issues did arise - namely, during the constitutional debates of 1974-75, which gave rise to the NPG - alignments cut across party lines. The nature of the coalition that replaced Somare in 1980 (see above) suggested further that issues were secondary to strategies for achieving parliamentary office, a view reinforced by the 1978 split in the UP and demonstrated in political behaviour ever since.

Among later-established parties, the MA, under the leadership of former Catholic priest John Momis and Bernard Narokobi, has been seen as a relatively socially progressive party; there have been several 'labour' parties, the most recent, the Papua New Guinea Labour Party, linked to the Papua New Guinea Trade Union Congress; there was a short-lived Socialist Democrat Party, 'The True People's Party', established by former student leader Gabriel Ramoi; a Christian Democratic Party was launched in 1995, 'with the vision to provide Christian Leadership in all levels of government'; and a United Resources Party emerged during the 1997-2002 Parliament with a platform that emphasised equitable returns from resource development. But none of these has done much to further the cause of issue-based politics. In the 1980s, there were suggestions that emerging social class divisions might provide a basis for political party development, but subsequent developments have not provided the evidence for such a view.

In the absence of class or ideological cleavages, ethnic or regional divisions seemed to be a likely base for political aggregation. The visiting UN mission in 1971 expressed concern at the regionalist tendencies in political party development, ${ }^{33}$ and the next year a local scholar forecast that 'it will not be ideology or class interests which separate the parties - if there are more than one ... regional interests are the most likely source from which political parties will derive their mass base'. ${ }^{34}$ Commentaries on the 1977 election tended to support this judgment: Hegarty observed that in the pre-election period 'considerable social differentiation had become apparent', but went on to conclude, 'The basic cleavages in PNG politics are not ideological or class based but regional', 35 and Premdas and Steeves ventured the opinion, 'It would be difficult for anything but an ethnically-based party system to emerge. ${ }^{36}$ By the 1980 s, the regional concentration of party support appeared to have been diluted somewhat, ${ }^{37}$ nevertheless, there was still evidence of a regional element in party support: Pangu had its strongest support from the East Sepik and Morobe Provinces (in the case of East Sepik, Pangu support merged with loyalty to the provincial member, Pangu leader and 'father of the nation', Michael Somare), though from 1982 it began gaining support in parts of the Highlands; PPP and MA were strongest in the New Guinea Islands region; and UP, NP, Country Party, and subsequently PDM were associated primarily with Highlands politicians. More specifically, a Morobe District People's Association (MODIPE) had been established in 1973 with the objective of preventing people from outside Morobe Province becoming parliamentary members for Morobe electorates (at this time, the Pangu member for Lae was a 
Papuan), and, in 1987, this sentiment was revived by former Morobe Premier, Utula Samana, who launched a Morobe Independent Group (MIG) and led it successfully into the election that year. A more substantial regional influence has been that exercised by Papuans. This began with the election of Papua Besena leader, Josephine Abaijah, and the formation of the Papua Party; it continued with the formation of the NP-associated Papua Action Party and Diro's Independent Group, and the subsequent emergence of a Papuan Bloc in Parliament; these in turn provided the base of the PAP (initially a Papuan-dominated party, though in recent years it has received substantial support from the Highlands); after being elected in 1992 as an NP candidate, Skate formed the PNGFP, a Papuan-based party, and, in 1997, as leader of the PNC — a party with six Papuan MPs — he became the country's first Papuan Prime Minister.

\section{Longevity of parties}

Not surprisingly, in this context, the majority of parties that have emerged over the years has been short-lived. There has been a proliferation of parties at each election, but those that do not achieve electoral success mostly disappear soon after the election. Many of these are essentially one-person parties.

Of the parties currently represented in the National Parliament, Pangu has enjoyed a continuous history as a major player since 1967 , though it has suffered two major breakaways and is currently (early 2005) split into two factions; PPP also has a continuous record as a major party, though it too, is currently divided between two factions: UP and NP have survived, but with periods of low activity and records of factionalism; the MA has been a small but significant actor since its formation in 1980; and the PDM, PAP and NA have now been around, if sometimes fractious, for several years. Beyond that, parties have tended to come and go quite rapidly, mostly just before and just after elections.

\section{The OLIPPC, LPV and parties since 2002}

In the latter half of the 1990s, there was considerable dissatisfaction within PNG about the country's lack of social and economic progress and growing problems of lawlessness and corruption, and growing criticism from outside. On becoming Prime Minister, Morauta vowed to address these issues and 'to restore integrity to our great institutions of state'. A major plank in his government's reform platform was an Organic Law on the Integrity of Political Parties and Candidates (OLIPPC). A secondary measure was an amendment to the Organic Law on National and Local-level Government Elections to change the electoral system from one of first-past-the-post voting to one of limited preferential voting. ${ }^{38}$

In each national election in PNG since 1972, there has been a steady increase in the number of candidates contesting, notwithstanding an increase in the required fee for candidature in 1992, from K100 to K1,000 (then roughly equal to per capita GDP). While some of these candidates might have been put up to split the local vote of a rival candidate in another clan or another part of the electorate, with voter support being localised there are often several candidates with a good chance of winning if they can hold their support base together. There has also been a fairly steady increase in the 
proportion of candidates who have stood — at least overtly — as independents. These developments have had at least two adverse effects on elections: first, with the number required for victory sometimes relatively small in open electorates with many candidates, holding one's bloc together is critical, and this has encouraged voting irregularities and violence in parts of the country, especially in the Highlands. In 2002, this caused the declaration of failed elections in six of the nine electorates in the Southern Highlands. Secondly, with many candidates competing, the percentage of the total vote that winning candidates have obtained has been, on average, steadily falling. Concerns about these issues lay behind the OLIPPC.

After widespread public consultation, organised through a Constitutional Development Commission, and parliamentary debate, the OLIPPC and associated constitutional amendments were passed in December 2000 and came into force in 2001, in time for the country's sixth post-independence elections. In a foreword to an explanation of the proposed legislation by the CDC, Prime Minister Morauta described the initiative as 'the most important Constitutional change this country has made since independence'. ${ }^{39}$ Its broad objectives were to strengthen the party system and help return stability and integrity to politics.

The OLIPPC contains four main provisions.

\section{Party registration}

Political parties must be registered with the Registrar of Political Parties, an office created under the OLIPPC and independent of the Electoral Commission. An unregistered party cannot nominate candidates for election. Parties must submit details of membership and a constitution, and provide financial returns on an annual basis. Membership is not to be confined to people from a particular province, region or group and the party must not encourage regionalism or secession. ${ }^{40}$ Party offices are to be 'elected in a democratic manner' (spelled out in the legislation). Party members must be paid-up, and a person cannot be a member of more than one party. Provision is made for cancellation of registration (inter alia, if a party fails to file financial returns for two consecutive years), for dissolution of a registered party (where a majority of party members or 75 per cent of party MPs agree), and for amalgamation of registered parties. In addition to the Registrar, the OLIPPC set up a Central Fund Board of Management (renamed Commission on the Integrity of Political Parties and Candidates), whose membership comprises the Registrar, the Electoral Commissioner, the Clerk of the National Parliament, the chair of the National Economic and Fiscal Commission, and church and women's representatives. The board appoints the Registrar and is responsible for dealing with registration applications and management of the Central Fund. By August 2001, 43 parties had registered (though not all had supplied the necessary documentation).

\section{Funding of parties and candidates}

The OLIPPC established a Central Fund, from which parties receive public funding. The sources of income available to the Central Fund comprise an annual appropria- 
tion from the national budget and (unlimited) contributions from citizens, international organizations and non-citizens. The allocation to parties is on the basis of K10,000 for each elected MP. In 2003, the Central Fund Board of Management approved the distribution of K990,000 to 20 parties, at the same time complaining that 'The government has miserably failed to adequately fund the Board and its Secretariate [sic]'. ${ }^{41}$

In addition, registered parties and candidates can receive contributions from citizens and non-citizens of up to K500,000 in any financial year, in each case - a somewhat generous provision, especially considering that the Constitution in 1975 precluded non-citizen contributions, and the CDC initially recommended a limit of K100,000. The donor and the recipient are required to provide details of such contributions to the Registrar, though there have been complaints that the Registrar has not been fully informed. Successful candidates are also required to submit a detailed financial statement within three months of election.

\section{Strengthening political parties in Parliament}

Probably the most important provisions of the OLIPPC were those intended to prevent 'party-hopping'. Under the organic law, a Member of Parliament who was elected as a party-endorsed candidate cannot withdraw or resign from that party during the life of the Parliament (unless he/she can establish that the party or an executive of the party has committed a serious breach of the party's constitution or that the party has been adjudged insolvent) and cannot vote against a resolution of the party concerning a vote of no confidence, the election of a Prime Minister, approval of the national budget or a constitutional amendment (a member can, however, abstain from voting). Contravention of this provision is regarded as resignation from the party and sets in motion a series of procedures that can culminate in the member having to reimburse the party for all campaign and other expenses received from the party, exclusion from appointment as a minister or committee chair, or dismissal from Parliament. A member elected as an independent can join a party after the initial vote for prime minister, and then incurs the same obligations to the party as a partyendorsed candidate. A member elected as an independent who remains independent, but who supported a particular candidate in the vote for prime minister, must not vote against that candidate or his/her government in a subsequent vote of no confidence, nor against a budget brought down by that government, nor against a constitutional amendment proposed by that government.

These provisions were tested in December 2003, when the Somare Government, already facing threats of a vote of no confidence, sought to extend, from 18 months to 36 , the grace period within which an incoming government was free from a vote of no confidence. The proposed constitutional amendment was defeated, but several parties split over the issue. Some members who voted against their party leader defended themselves by arguing that there had not been a formal party resolution on the issue. The issue has not to date been resolved. 
The OLIPPC also provides that, after an election, the Head of State shall invite the party with the greatest number of endorsed candidates elected to form a government and to nominate a candidate for election by the Parliament as Prime Minister. This was intended to minimise the post-election lobbying that had produced the 'lock-ups' after earlier elections. ${ }^{42}$ In 2002, this probably gave an advantage to Somare, as leader of the NA, and Somare was duly elected Prime Minister, but it did not eliminate the post-election machinations and it did not necessarily ensure a victory for Somare.

\section{Incentives for female candidates}

In an effort to address the massive under-representation of women as electoral candidates and in the National Parliament, the OLIPPC provided that where a party-endorsed female candidate received at least 10 per cent of the votes cast in her electorate, the Central Fund would reimburse up to 75 per cent of the campaign expenses outlaid on her by the party. In 2002, the number of female candidates (mostly independents) rose from 45 to 74 , but the number elected fell from two to one, and only received 10 per cent of the vote.

Before the 2002 national elections, 43 parties had registered with the Registrar for political parties, though many of these had very small membership and, on the eve of polling, a number had not provided the Registrar with the required list of candidates. In the event, with 'failed elections' declared in six seats in 2002, 24 parties were represented in the new Parliament: the NA with 19 members, PDM 13, PPP eight, Pangu six, PAP five, People's Labour Party four, nine parties with two or three members and another nine with one member each. Seventeen candidates were elected as independents. By December 2003, the number of parties had been reduced, through amalgamations, to $18 .{ }^{43}$ As the leader of the party with the most winning candidates in 2002, Somare was invited to form a government, and he was subsequently elected Prime Minister by a vote of 89 to nil, with 14 members abstaining. The PDM, under Morauta, joined the small Opposition group, subsequently changing its name to the Papua New Guinea Party (PNGP). Wingti was re-elected in 2002, but he stood as an independent and did not seek to regain leadership of the party he had established.

The shift from first-past-the-post voting to limited preferential voting (LPV) was affected in the general belief that such a change would bring about greater cooperation between candidates, reducing the number of candidates and lessening the violence associated with recent elections - though the rationalization of this belief has never been made very clear. ${ }^{44} \mathrm{LPV}$ came into effect after the supplementary elections in the Southern Highlands in 2003. By December 2004, there had been six by-elections held under LPV. All were fairly peaceful affairs, with fewer candidates than in the 2002 national elections, but since that is usual in by-elections it would be premature to take these outcomes as a validation of this particular piece of social engineering. 


\section{Why has a coherent party system failed to develop in PNG?}

The question, why have parties not developed, implicitly assumes that political parties are an inherent part of a parliamentary system. Certainly, the process of majority decision-making encourages groups of like-minded members to come together to ensure the numbers necessary to push legislative agendas, and when there are significant lines of social cleavage - class, ideology, ethnicity, religion, region — and corresponding clearly differentiated collective group interests, these might form a natural basis for party organisation. This has been the history of political party development in most developed nations. But it does not describe politics in PNG.

First, as Hegarty has argued, PNG lacked the galvanising influence on politics of an independence struggle, through which parties have often been defined elsewhere, ${ }^{45}$ and, after the early differences between Pangu-NP and UP over the speed of transition to independence became irrelevant in 1975, party platforms, as we have seen, tended to converge. Class has not emerged as a major social cleavage in a country where about 85 per cent of the population is at least partly involved in subsistence agriculture and even the urban elite tend to retain their links with the village. Undoubtedly, there is a growing gap between rich and poor, but Western class models are largely irrelevant in explaining the dynamics of economic inequalities in PNG. Regionalism has had more impact on PNG politics, especially in relation to a continuing Papuan identity, but it has not provided a systematic basis for party organization. Indeed, to achieve office, all coalitions need to put together a group representative of all four regions, and this to some extent cuts across regionalism as a base for party organisation. In the absence of such social or geographic cleavages, collectivities have developed primarily from personal networks. Since politicians also compete for office, these personal networks are typically fragile, especially among aspiring leaders.

Secondly, and not unrelated, politics in PNG remain essentially parochial. While I have argued elsewhere that the view of electoral outcomes in PNG being determined by clan or 'tribal' loyalties is an oversimplification, electoral success nevertheless seems to be determined primarily by local factors: local reputation, local perceptions of a candidate's ability to deliver goods and services to his or her electorate and the effectiveness of electoral campaigning. Successive studies of PNG national elections have provided little evidence of a party vote - even of a strong Pangu vote in Pangu's stronghold of East Sepik - and only occasionally (as perhaps in the case of Sir Michael Somare, the country's first Prime Minister) has a national reputation translated into local votes. Added to this, a high turnover of parliamentary members means that most MPs seek a quick return from their period in office, and this places a premium on being in government, preferably with a Cabinet portfolio. Indeed, MPs' constituents generally expect their member to be in government, regardless of party attachment. After several Opposition MPs defected to governing coalition parties in 1990, they explained: 'We are elected to Parliament to be in government. ${ }^{36}$

As a result, MPs are driven less by the desire to implement a particular policy agenda than by the desire to maximise the returns, for themselves and their constituents, 
from being in office. And as every government since 1972 has been a coalition and, until 2002, no government has survived a full parliamentary term, with MPs hopping from one party to another and parties shifting allegiance from one coalition to another, the potential for individual interest outweighing party loyalty is substantial. This has been reflected in the frequency of votes of no confidence. In such a volatile atmosphere, party loyalties are difficult to sustain. OLIPPC sought to address this problem by strengthening parties, but developments since December 2003 have so far suggested that MPs are not willing to accept the constraints of the OLIPPC and that the State is either incapable of enforcing the provisions of the organic law or unwilling to pursue them.

\section{Prospects for future party development}

If political parties in PNG could play a role in mobilising electors and defining issues that cut across narrow clan or local identity interests, if they could play a role in selecting capable and effective candidates to become MPs, if they could provide an organisation and discipline to control the parliamentary behaviour of MPs - the functions traditionally associated with parties in liberal democracies - they could make a substantial contribution to the achievement of a less fractious political system, in which the Legislature legislates and the Executive takes the lead in governing. There is no real evidence that this happening, or, in the light of experience to date with OLIPPC, that it will happen. As has been argued above, since the 1980s, political parties seem to have become more, rather than less, fluid, weaker in terms of organisation and finance, and have a shorter life expectancy. Those inside and outside PNG who argue, largely on the basis of developed Western country experience, that parties will develop but that, as in developed Western countries, the process 'will take time', have not produced a convincing argument to support this social Darwinist assumption. Almost 30 years after independence, political allegiances are still heavily personalised and significantly localised, with a poorly developed sense of national identity. State institutions are mostly weak, and, in the absence of the sort of major social cleavages that characterised political party development in the West, there is no obvious reason why this should change. Moreover, PNG is not unique: in many countries, mass-based political parties are weak and play a secondary role to personalised parliamentary factions.

In 1970, a frustrated young political organiser, Michael Somare, observed: 'The administration is the giver of all things and people do not care so long as they are at the receiving end. Our people are so accustomed to getting things for nothing that ... they do not see why they should organise as political groups. ${ }^{47}$ Thirty years later, people were not 'so accustomed to getting things for nothing', but they still tended to see the State as the source of things, and getting access to the State meant getting their candidate elected. Once in Parliament, MPs hope to improve their access to things by becoming part of government, and, with weak party allegiance and discipline, parliamentary alliances are constantly shifting. Institutional change, through the OLIPPC, has so far done little to change this pattern. What is needed to bring about change is a fundamental shift in behaviour, and, in the foreseeable future, it is not clear what could bring about such a change. 


\section{Footnotes}

1 May, R. J. 1984. 'Class, ethnicity, regionalism and political parties.' In R. J. May (ed.), Social Stratification in Papua New Guinea, Working Paper No. 5, Canberra: Department of Political and Social Change, Research School of Pacific Studies, The Australian National University. pp. 174-90 (reprinted in May, R. J. 2001. State and Society in Papua New Guinea: The First Twenty-Five Years. Adelaide: Crawford House Publishing. pp. 127-146).

2 For a more detailed history of political parties in Papua New Guinea, see Wolfers, E. P. 1970. 'A short history of political party activity in Papua New Guinea.' In M. W. Ward (ed.), The Politics of Melanesia, Fourth Waigani Seminar. Canberra: The University of Papua New Guinea and ANU. pp. 439-88; Stephen, D. 1972. A History of Political Parties in Papua New Guinea. Melbourne: Lansdowne Press; Loveday, P. and E. P. Wolfers, 1976. 'Parties and Parliament in Papua New Guinea 1964-1975.' IASER Monograph, No. 4. Port Moresby: Institute of Applied Social and Economic Research; May, 1984, ibid.; Okole, Henry T. 2004. 'The Fluid Party System of Papua New Guinea: Continuity and Change in a Third Wave Democracy.' Unpublished PhD thesis, Northern Illinois University; and May, R. J. 2004. 'Papua New Guinea.' In Alan J. Day and Henry W. Degenhardt (eds), Political Parties of the World, London: John Harper Publications. Also see Faircloth, Susan, Hartmut Holzknecht and R. J. May. 1978. 'Politics and Government in Papua New Guinea.' IASER Bibliography, No. 4. Port Moresby: Institute of Applied Social and Economic Research. pp. 141-6. The role of political parties is also discussed in a series of studies of PNG's national elections: Epstein, A. L., R. S. Parker and M. Reay (eds). 1971. The Politics of Dependence: Papua New Guinea 1968. Canberra: ANU Press; Stone, David (ed.) 1976. Prelude to Self-Government. Electoral Politics in Papua New Guinea 1972. Canberra: RSPAS-ANU, and UPNG; Hegarty, David (ed.) 1983. Electoral Politics in Papua New Guinea. Studies on the 1977 National Elections. Port Moresby: UPNG Press; King, Peter (ed.) 1989. 'Pangu Returns to Power: The 1982 Elections in Papua New Guinea.' Political and Social Change Monograph, No. 9. Canberra: DPSC, RSPAS-ANU; Oliver, Michael (ed.) 1989. Eleksin. The 1987 National Election in Papua New Guinea. Port Moresby: UPNG; Saffu, Yaw (ed.) 1996. 'The 1992 PNG Election: Change and Continuity in Electoral Politics.' Political and Social Change Monograph, No. 23. Canberra: DPSC, RSPAS-ANU; May, R. J. and Ray Anere (eds). 2002. Maintaining Democracy: The 1997 Elections in Papua New Guinea. Port Moresby: Department of Political Science, School of Humanities and Social Sciences, UPNG and State, Society and Governance in Melanesia Project (SSGM), ANU. From 1967 to 1991, the Australian Journal of Politics and History contained a regular chronicle of developments in PNG written by various Port Moresby-based authors, which provides valuable source material; these chronicles have been brought together in Clive Moore with Mary Kooyman (eds). 1998. A Papua New Guinea Political Chronicle 1967-1991. Bathurst: Crawford House Publishing [references to these chronicles in this paper will be to the Moore with Kooyman volume].

3 Canberra Times, June 23, 1967.

4 Wolfers recalls that during the 1960s, police Special Branch personnel 'were regularly to be observed taking notes' at meetings of political parties (see Epstein, Parker and Reay, op. cit., p. 30).

5 Kiki, Albert Maori. 1968. Ten Thousand Years in a Lifetime. Melbourne: F. W. Cheshire. p. 175. Also see Somare, Michael. 1970. 'Problems of political organization in diversified tribes in Papua-New Guinea.' In M. W. Ward (ed.), op. cit.; and Somare, Michael. 1982. 'The role of political parties in Papua New Guinea.' Administration for Development, Vol. 9. pp. 3-8.

6 Stone (ed.), op. cit. p. 51.

7 See R. J. May. 'The political education programme.' In Stone (ed.), ibid., pp. 107-26.

8 United Nations. 1968. Report of the United Nations Visiting Mission to the Trust Territory of New Guinea. Document T/1717. p. 66.

9 Epstein, Parker and Reay (eds), op. cit., p. 326.

10 Wolfers, E. P. 1998. 'Political Chronicle January-April 1968.' In Moore with Kooyman (eds), op. cit. p. 36.

11 See Wolfers, E. P. 1970, op. cit.; and Stephen, D., op. cit.

12 The leaders of several other 'micronationalist' movements that emerged about this time also contested elections, some successfully, but did not see themselves as political parties (see R. J. May [ed.] 1982. 'Micronationalist Movements in Papua New Guinea'. Political and Social Change Monograph, No. 1. Canberra: DPSC, RSPAS-ANU. Chapter 1). 
13 Loveday and Wolfers, op. cit. p. 21.

14 Ibid.

15 Ibid. p. 74.

16 Stone, op. cit. p. 535.

17 Sections 129-130 of the Constitution of the Independent State of Papua New Guinea stipulated that parties were to be registered and political contributions limited; contributions to parties and candidates by non-citizens were specifically precluded.

18 See Hegarty, D. 'Political Chronicle January-June 1975.' In Moore with Kooyman (eds), op. cit. pp. 236-40.

19 See McKillop, R. F. 1982. 'Papua Besena and Papuan separatism.' In May (ed.), 1982, op. cit. pp. 329-58.

20 Hegarty, D. 'Political Chronicle January-June 1977.' In Moore with Kooyman (eds), op. cit. p. 300.

21 See Hegarty, ibid. and Hegarty (ed.), 1983, op. cit. Chapter 1.

22 Standish, W. 1977. 'Independent Papua New Guinea’s first national elections: an interim report.' Dyason House Papers, Vol. 4, No. 1. p. 4.

23 See, for example, Post-Courier, June 21, 1983.

24 See Daro, B. B. 1976. 'The Papua Besena movement; Papua dainai, tano dainai, mauri dainai.' IASER Discussion Paper, No. 7, Port Moresby: Institute of Applied Social and Economic Research; McKillop, op. cit.

25 Hegarty, David and Peter King. 1998. 'Political Chronicle January-June 1982.' In Moore with Kooyman (eds), op. cit. p. 357.

26 See May, R. J. 1989. 'The East Sepik electorates.' In Peter King (ed.), Pangu returns to power: the 1982 elections in Papua New Guinea, Canberra: DPSC, RSPAS-ANU, pp. 221-7.

27 Hegarty and King, 1998, op. cit. p. 361.

28 See Saffu, Yaw. 1989. 'Survey evidence on electoral behaviour in Papua New Guinea.' In M. Oliver, op. cit. pp. 15-36.

29 Post-Courier, August 6, 1987.

30 Saffu, Yaw. 1998. 'Political Chronicle January-June 1988.' In Moore with Kooyman (eds), op. cit. p. 455.

31 See May, R. J. 1996. 'Election in the East Sepik: Mit na Bun.' In Yaw Saffu (ed.), 1996, op. cit. pp. 219-39.

32 Saffu, Yaw. 1989. 'Survey evidence on electoral behaviour in Papua New Guinea'. In Michael Oliver (ed.), Eleksin: The 1987 National Election in Papua New Guinea. Port Moresby: UPNG. p. 30-31.

33 United Nations, op. cit. p. 176.

34 Waddell, J. R. E. 1973. 'Constitutions and the political culture.' In A. Clunies Ross and J. Langmore (eds), Alternative Strategies for Papua New Guinea. Melbourne: Oxford University Press. p. 96.

35 Hegarty (ed.), 1983, op. cit. pp. 454, 461.

36 Premdas, R. R. and J. S. Steeves. No date. Political parties and electoral politics in Papua New Guinea. The case of the Moresby North-East electorate. Port Moresby: UPNG. p. 35.

37 Cf. Jackson, Richard and David Hegarty. 1983. 'From geography to ideology?' Australian Geographer, Vol. 15, No. 5. pp. 334-6.

38 In an unpublished paper ('Political change in Papua New Guinea: Is it needed? Will it work?') presented to a conference at the Divine Word University, Madang, 2003, I questioned some of the assumptions underlying the 2001 reforms. Some of those questions remain valid. For more recent analyses of the operation of the OLIPPC, see Baker, Louise. 2003. Political Integrity in Papua New Guinea and the Search for Stability. Canberra: AusAID; and Gelu, Alphonse. 2005. 'The failures of the Organic Law on the Integrity of Political Parties and Candidates.' Unpublished paper presented to the Pacific Islands Workshop, Asia Pacific Week, RSPAS/International Centre of Excellence-Asia Pacific, ANU, January-February 2005.

39 Explaining the Proposed Political Integrity Laws Prepared by the Constitutional Development Commission, Waigani, July 2000. p. 1.

40 The term 'regionalism and secession' is taken from Bengo, Paul. 2002. Brief on Provisions of the Organic Law on the Integrity of Political Parties and Candidates for Members of the Seventh Papua New Guinea National Parliament by the Registrar, July 2. p. 4. The Organic Law itself (S.7 [a]) does not specifically mention 'regionalism'. 
41 Central Fund Board of Management. 2003. 'Press Release on Financial Returns of and Funding to Registered Political Parties for 2002.' March 11.

42 Another provision of the OLIPPC made it an offence to force, threaten, intimidate, detain or otherwise interfere with the free movement of an MP in the performance of his parliamentary duties.

43 A list of parties and some detail on the larger parties can be found in R. J. May, 2004, op. cit.

44 Cf. Rumsey, Alan. 1999. 'Social Segmentation, Voting, and Violence in Papua New Guinea.' The Contemporary Pacific, Vol. 11, No. 2. p. 327; Reilly, Benjamin. 2001. Democracy in Divided Societies: Electoral Engineering for Conflict Management. Cambridge and New York: Cambridge University Press. pp. $88-9$.

45 See Hegarty, David. 1979. 'The political parties.' In A. Amarshi, K. Good and R. Mortimer (eds), Development and Dependency. The Political Economy of Papua New Guinea, Melbourne: Oxford University Press. p. 187.

46 Post-Courier, April 17, 1990, quoted in Saffu, Yaw. 1998. 'Political Chronicle January-December 1990.' In Moore with Kooyman (eds), op. cit. p. 488.

47 Somare, 1970, op. cit. p. 490. 